\title{
Genomic and functional conservation of IncRNAs: lessons from flies
}

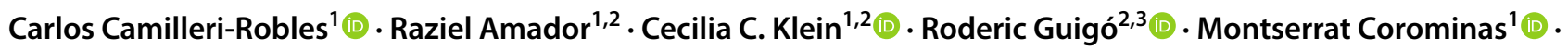 \\ Marina Ruiz-Romero ${ }^{2}$ (D)
}

Received: 17 June 2021 / Accepted: 9 December 2021 / Published online: 31 January 2022

(c) The Author(s) 2021

\begin{abstract}
Over the last decade, the increasing interest in long non-coding RNAs (lncRNAs) has led to the discovery of these transcripts in multiple organisms. LncRNAs tend to be specifically, and often lowly, expressed in certain tissues, cell types and biological contexts. Although IncRNAs participate in the regulation of a wide variety of biological processes, including development and disease, most of their functions and mechanisms of action remain unknown. Poor conservation of the DNA sequences encoding for these transcripts makes the identification of IncRNAs orthologues among different species very challenging, especially between evolutionarily distant species such as flies and humans or mice. However, the functions of lncRNAs are unexpectedly preserved among different species supporting the idea that conservation occurs beyond DNA sequences and reinforcing the potential of characterising lncRNAs in animal models. In this review, we describe the features and roles of lncRNAs in the fruit fly Drosophila melanogaster, focusing on genomic and functional comparisons with human and mouse lncRNAs. We also discuss the current state of advances and limitations in the study of lncRNA conservation and future perspectives.
\end{abstract}

Keywords LncRNAs · Drosophila melanogaster $\cdot$ Flies $\cdot$ Conservation $\cdot$ Comparative genomics $\cdot$ Development

\section{Introduction}

Long non-coding RNAs (lncRNAs), are DNA sequences encoding transcripts larger than $200 \mathrm{nt}$ that lack proteincoding potential. Although many lncRNAs show low levels of expression, some are known to play a pivotal role in the regulation of several cellular processes. In recent years, the amount of available transcriptomic data has increased exponentially and has been crucial in demonstrating that genomes are extensively transcribed. Additionally, the emergence of tools to identify putative non-coding genes has led to the annotation of a large number of lncRNAs not only in

Marina Ruiz-Romero

marina.ruiz@crg.eu

1 Departament de Genètica, Microbiologia I Estadística, Facultat de Biologia and Institut de Biomedicina (IBUB), Universitat de Barcelona, Barcelona, Catalonia, Spain

2 Centre for Genomic Regulation (CRG), The Barcelona Institute for Science and Technology (BIST), Barcelona, Catalonia, Spain

3 Universitat Pompeu Fabra (UPF), Barcelona, Catalonia, Spain humans, but also in mice, insects and plants (Brown et al. 2014; Derrien et al. 2012; Lagarde et al. 2017; Legeai and Derrien 2015; Paytuví Gallart et al. 2016; Pervouchine et al. 2015).

The most updated version of the human genome annotation contains 19,951 protein-coding genes and 17,948 IncRNA genes (GENCODE v37, March 2021). In contrast to protein-coding genes, whose molecular functions can often be inferred by the presence of protein domains, inferring the function, if any, of lncRNAs is a whole different story. Although some lncRNAs have been functionally characterised in humans (Rinn et al. 2007; Tripathi et al. 2010; Wutz et al. 2002; Zhou et al. 2007), the frequent absence of phenotypes after their mutation or deletion has raised questions about the proportion of annotated lncRNAs that are actually functional (Gao et al. 2020; Lee et al. 2019).

High-throughput screens of lncRNA knock downs affecting molecular phenotypes have been performed in human cells (Liu et al. 2017, 2018; Ramilowski et al. 2020). However, the difficulties in conducting functional genetic screens in humans and other vertebrates in vivo limit the ability to characterise the role of annotated lncRNAs in these species, pointing out the need to use less 
complex model organisms. One of the most useful animal models for genetic analyses is the fruit fly Drosophila melanogaster, whose genome contains 13,969 protein-coding and 2545 long non-coding RNA annotated genes (FlyBase r6.39, February 2021). A huge advantage of using Drosophila as an animal model is the availability of a great variety of genetic tools, resources and mutant collections that facilitate the undertaking of genetic screens. Forward genetic screens use mutagenesis to create random mutations in the search for the genotypes that underlie the resulting phenotypes. They have been instrumental in identifying the function of protein-coding genes $(\mathrm{St}$ Johnston 2002). On the contrary, reverse genetic assays are preferentially used to screen for IncRNAs, searching for phenotypes after creating targeted mutations in candidate genes (Wen et al. 2016). Compared to protein-coding genes, in which a single nucleotide deletion or insertion can abolish the production of the proteins they encode, the deletion of a large region encompassing the whole gene, smaller specific domains or the promoter, may be required to compromise the function of lncRNAs. The existence of different systems for the conditional expression of transgenes (both for inhibition and/or overexpression), widely used to assess protein-coding genes, may also contribute to understanding the function of lncRNAs.

It is well known that fundamental biological mechanisms and signalling pathways are conserved throughout evolution. An estimated $75 \%$ of genes related to human diseases have orthologs in the Drosophila genome (Bier 2005; Ji et al. 2019), endorsing the study of human diseases in flies. In this context, several lncRNAs have been associated with cancer (Dong et al. 2015; Li et al. 2014, 2015; Wu et al. 2014), and many neurological disorders, such as amyotrophic lateral sclerosis ( $\mathrm{Zu}$ et al. 2013), Alzheimer's disease (Lee et al. 2015) and Huntington's disease (Johnson 2012). Although no fly orthologs have been identified for lncRNAs associated to human diseases, the study of lncRNAs in Drosophila could shed light into the regulation of disease-causing genes ( $\mathrm{Li}$ et al. 2012; Lo Piccolo and Yamaguchi 2017; reviewed in Rogoyski et al. 2017).

In this review, we discuss lncRNAs in the fly genome and compare them with human and mouse lncRNAs. Furthermore, we provide an overview of the functions and mechanisms of action associated with lncRNAs in Drosophila, including similarities in the function of some lncRNAs between flies and humans. We also characterise developmentally dynamic fly $\operatorname{lncRNAs}$ that are differentially expressed during tissue development, and report resemblances among these lncRNAs and the ones identified in human and mouse organ development (Sarropoulos et al. 2019). Finally, we discuss the current status of identifying orthologues in evolutionarily distant species such as flies and humans.

\section{Genomic and transcriptomic comparison between flies, mice and humans}

Drosophila has four pairs of chromosomes: one pair of sexual chromosomes and three pairs of autosomes. In flies, similar to what happens in mice and humans, sex is determined by the $\mathrm{XX} / \mathrm{XY}$ mechanism, with females carrying two $\mathrm{X}$ chromosomes and males carrying one $\mathrm{X}$ and $\mathrm{Y}$ chromosomes. In mammals, the presence of the $\mathrm{Y}$ chromosome determines the male sex, while its absence results in female individuals. However, the Y chromosome is not involved in sex determination in flies. Instead, the $\mathrm{X}$ :A ratio is responsible for the activation of the feminizing gene Sex-lethal (sxl). Hence, flies carrying XY or $\mathrm{X} 0$ are male, while flies carrying XX or XXY are female. The Drosophila genome is small, with approximately 120 megabases, (Adams et al. 2000) compared to the human and mouse genomes (3100 and 2700 megabases, respectively) (Lander et al. 2001; Venter et al. 2001; Consortium et al. 2002) (Fig. 1a). This is consistent with the reduced number of annotated genes in Drosophila $(17,874)$ compared to humans and mice $(45,468$ and 39,923 genes, respectively). This trend is preserved for both proteincoding genes (13.969 genes in flies compared to 19,951 and 21,848 genes in humans and mice, respectively) and lncRNA genes (2545 genes in Drosophila compared to 17,948 and 13,186 genes in humans and mice, respectively) (Fig. 1b). Remarkably, the number of lncRNAs in Drosophila is considerably smaller compared to proteincoding genes, whereas in mice and humans the number of lncRNAs and protein coding-genes is similar (Fig. 1b). Furthermore, the Drosophila genome is much more compact, containing around 100 protein-coding and 18 lncRNA annotated genes per megabase compared to fewer than 10 protein-coding and lnRNA genes per megabase in the human and mouse genomes (Fig. 1c).

LncRNAs are pervasively distributed throughout the genome and can be found in intergenic regions (lincRNAs) or overlapping totally or partially with sequences of other genes transcribed in the same direction (sense) or in the opposite direction (antisense). Despite the differences in genome compactness among Drosophila, mice and humans, lincRNAs represent $50-55 \%$ of all annotated IncRNAs in the three species. Similarly, the proportion of lncRNAs found overlapping the introns (intronic) or exons (exonic) of other genes accounts for $\sim 20 \%$ and $\sim 25 \%$, respectively, in all three species (Fig. 1d). Regarding the number of exons, the majority of IncRNAs found in Drosophila are either mono-exonic or composed of 2 exons, with only a few exceptions containing 3 or more exons. On the contrary, the number of exons in human and mouse lncRNAs is more diverse, with around $60 \%$ in each species 
A

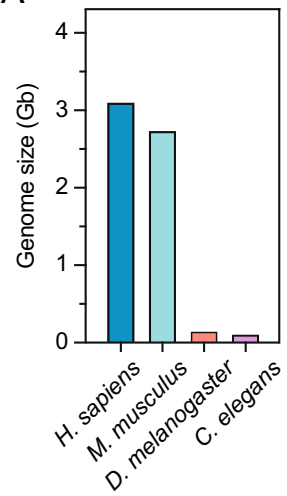

B

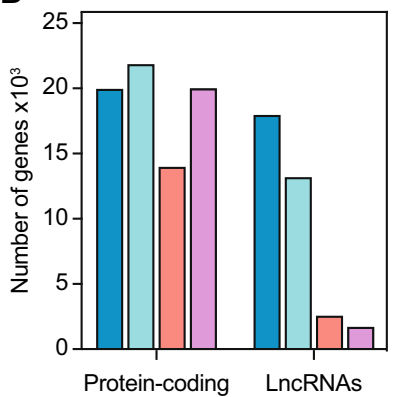

C

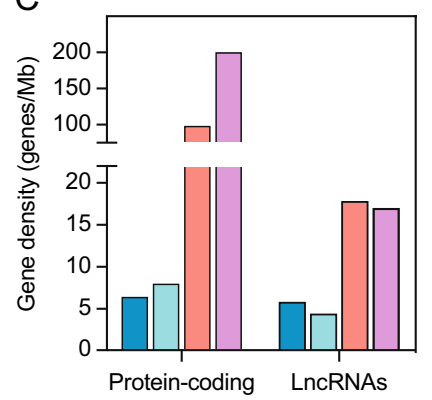

D

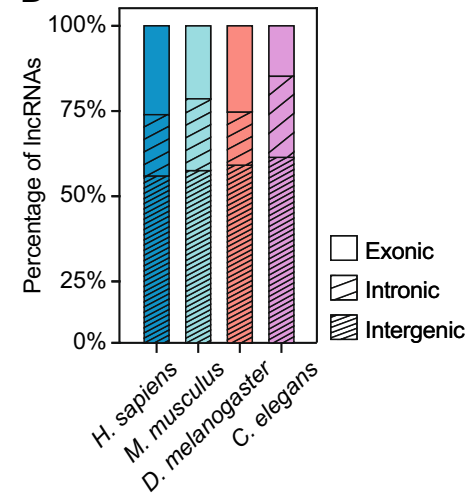

E

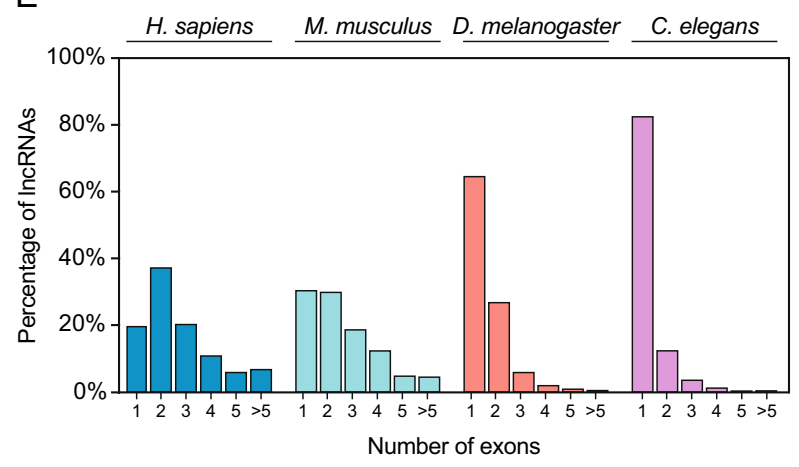

H. sapiens
M. musculus

Fig. 1 Genomic and transcriptomic comparison of humans, mice and flies. a Barplot showing the size (gigabases- $-\mathrm{Gb})$ of the human $(H$. sapiens), mouse (M. musculus), fly (D. melanogaster) and worm $(C$. elegans) genome. b Number of annotated protein-coding and long non-coding RNA (lncRNA) genes in each species. c Gene density, measured as the number of genes per megabase, of protein-coding and lncRNA genes in each species. d Classification of the annotated lncRNA genes into exonic, intronic or intergenic groups. The longest annotated isoform of each lncRNA has been used for overlap analysis

containing 1-2 exons (compared to $90 \%$ in fly) and around $20 \%$ containing 4 or more exons (Fig. 1e). This is consistent with the proportion observed in protein-coding genes in flies (Graveley et al. 2011). In terms of transcript size, as with the protein-coding genes, Drosophila lncRNAs are shorter than human and mouse IncRNAs (average length of $962 \mathrm{nt}$ in flies compared to 1230 and $1456 \mathrm{nt}$ in humans and mice, respectively, Mann-Whitney-Wilcoxon test $p$-value $<1 \mathrm{e}-12$ for all comparisons). Only $3.35 \%$ of Drosophila lncRNAs span more than $3 \mathrm{~kb}$ compared to $7.78 \%$ in humans and $10.35 \%$ in mice (Fig. 1f).

The small number of lncRNA genes annotated in Drosophila, with respect to humans and mice may not be a biological feature, but it might rather reflect two factors that hinder the identification of IncRNAs in Drosophila. First,
$\mathrm{F}$

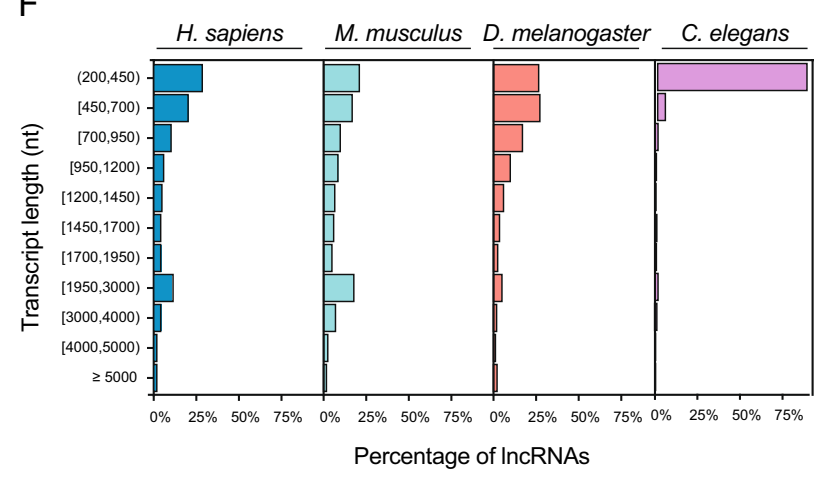

D. melanogaster $\square$ C. elegans and classification. e Distribution of the lncRNA genes annotated in human, mouse, fly and worm depending on their number of exons. f Distribution of the long non-coding genes of humans, mice, flies and worms based on the size (nucleotides-nt) of their longest transcript. Human data from GENCODE v37 are shown in blue, mouse data from GENCODE M27 are shown in cyan, fly data from FlyBase r6.39 are presented in red and worm data from WS281 are shown in pink

the properties of most lncRNAs (low expression and high specificity in terms of time and tissue) might constraint their expression to a specific region during a very specific period of time. Thus, the identification of these IncRNAs may require transcriptomic analyses in specific tissues and developmental stages, which are not as common in flies as they are in humans and mice. Supporting this hypothesis, a recent publication producing transcriptomic data from Drosophila embryonic mesodermal cells collected at different developmental stages identified 179 novel lncRNA genes that could play a role in embryogenesis (Schor et al. 2018). Second, the bias towards mono-exonic genes found so far in Drosophila could also affect the identification of novel lncRNA genes, since most identifying pipelines often omit novel mono-exonic transcripts in favour of spliced, multi-exonic 
transcripts to reduce false positives. To provide a global vision of the evolutionary trend we observed for lncRNAs in flies, we inspected the genome of the worm Caenorhabditis elegans (Fig. 1). Interestingly, the genomic features we interrogated indicate that lncRNAs in worms resemble fly lncRNAs compared to human and mouse lncRNAs.

\section{Functions and mechanisms of action of Drosophila IncRNAs}

Since the discovery of lncRNAs, several studies in mammals and flies have demonstrated that lncRNAs participate in a variety of cellular processes, such as development, differentiation and proliferation, and often contribute to the modulation of gene expression programmes (reviewed in Jandura and Krause 2017; Statello et al. 2021). Functional IncRNAs can be classified as cis-acting lncRNAs, when they act near their site of transcription within the same molecule, or trans-acting lncRNAs, which act far from their locus or in a different DNA molecule. In general, IncRNAs influence gene expression at three main levels: chromatin regulation, transcriptional regulation and post-transcriptional regulation (reviewed in Statello et al. 2021). On chromatin, some lncRNAs regulate the activity or localisation of chromatin regulatory complexes and transcription factors. These lncRNAs bind to specific chromatin regions and interact with proteins, facilitating or inhibiting their binding to targeted neighbouring genes, thereby promoting or repressing gene expression (Grote and Herrmann 2013; Jiang et al. 2015; Prensner et al. 2013; Rinn et al. 2007; Yap et al. 2010). At the transcriptional level, lncRNAs influence gene regulation directly by interacting with the transcriptional machinery, mediating or facilitating loops between promoters and enhancers (eRNAs) or, in some cases, the act of transcription or splicing of a lncRNA influence the transcription of nearby genes (reviewed in Statello et al. 2021). LncRNAs can also act at the post-transcriptional level by interacting with a plethora of RNA-binding proteins that contribute to mRNA stability, localisation, splicing or translation (Cao et al. 2017; Gumireddy et al. 2013; Lee et al. 2016; reviewed in He et al. 2019).

In the last few years, several lncRNAs have been characterised in Drosophila. Although most of them are not evolutionarily conserved across metazoans at the sequence level, some seem to participate in similar cellular processes as those in mammals, such as dosage compensation or Polycomb group (PcG)/Trithorax group (TrxG) regulation (reviewed in Murillo-Maldonado and Riesgo-Escovar 2019; Ringrose 2017; Samata and Akhtar 2018). In this section, we discuss the functions associated with fly lncRNAs, their level of conservation in mammals, and provide some specific examples.

\section{LncRNAs influencing chromatin regulation}

\section{LncRNAs involved in dosage compensation mechanisms}

As mentioned before, in Drosophila, sex is dictated by the $\mathrm{XY}$ sex-determination system. Comparable to that occurring in mammals, the imbalance in the expression of $\mathrm{X}$-linked genes between females and males is corrected by a dosage compensation mechanism, involving lncRNAs, which result in similar levels of expression of the genes in the $\mathrm{X}$ chromosome. However, in female mammals, one of the $\mathrm{X}$ chromosomes is subjected to inactivation, whereas in Drosophila, the transcription rate of the male $\mathrm{X}$ chromosome is almost doubled. These strategies share some mechanistic similarities, including the involvement of IncRNAs. In both cases, a lncRNA is responsible for recruiting chromatinmodifying complexes that drive the inactivation (in female mammals) or overactivation (in male flies) of the $\mathrm{X}$ chromosome. Briefly, in mammals, the lncRNA Xist is upregulated in one of the $\mathrm{X}$ chromosomes of the females at early embryonic stages and rapidly spreads along the $\mathrm{X}$ chromosome from which it is transcribed (Brockdorff et al. 1992; Brown et al. 1991, 1992). Polycomb repressive complex 2 (PRC2), a chromatin regulatory complex, is recruited by Xist and mediates the trimethylation of lysine 27 in the histone H3 tail (H3K27me3). This triggers the heterochromatinisation of the Xist-bound X chromosome, resulting in X chromosome inactivation (Lee et al. 1996; Penny et al. 1996; Wutz and Jaenisch 2000).

On the contrary, in flies, the male-specific lethal complex (MSL), composed of MSL proteins and the lncRNAs roX1 and $r o X 2$, is responsible for the overactivation of genes located in the $\mathrm{X}$ chromosome of Drosophila males. Although very different in size and sequence, $r o X 1$ and $r o X 2$ act redundantly to allow the binding of MSL2 and the other subunits of the complex, which target the X-chromosome in males (Meller and Rattner, 2002). The MSL subunits mediate the activation of the $\mathrm{X}$-chromosome genes by the acetylation of lysine 16 in histone H4 (H4K16ac) (Bone et al. 1994; Gelbart et al. 2009). In female flies, the Sex lethal (sxl) gene, is upregulated and the female-specific RNA-binding protein it encodes interacts with the $m s l 2$ mRNA to inhibit its translation, preventing the assembly of the MSL complex and the subsequent dosage compensation (Beckmann et al. 2005; Gebauer et al. 1998; Graindorge et al. 2013).

\section{LncRNAs mediating PcG and TrxG gene regulation}

PcG and TrxG proteins are key modulators of an evolutionarily conserved gene regulatory system. They are chromatin modifiers that operate antagonistically and were originally identified as part of an epigenetic cellular memory system that maintains repressed or active gene expression states. The 
first identified target genes of PcG and TrxG regulation were the fly Hox genes (reviewed in Kassis et al. 2017). Hox genes encode transcription factors that determine the allocation of segmental identity along the anterior-posterior body axis and when mutated, typically, lead to homeotic transformations (reviewed in Mallo and Alonso 2013). In Drosophila, Hox genes are organized in two separate gene clusters: the Antennapedia and Bithorax complexes (ANT-C and BX-C, respectively); and their expression is activated by the segmentation gene products in early fly development. Further characterisation of Hox loci allowed the identification of several elements that respond to PcG and TrxG genes, named Polycomb response elements (PREs) and Trithorax response elements (TREs) (Chan et al. 1994; Simon et al. 1993). Drosophila PcG and TrxG proteins are recruited to chromatin by targeting these PREs and TREs, which are cis-regulatory DNA elements essential for the regulation of several hundred developmental genes beyond Hox genes. The PcG and TrxG proteins are able to regulate their target genes in a complex and dynamic manner, modifying local chromatin depending on the state of the promoters and maintaining active (TrxG) or repressive (PcG) states. (reviewed in Kassis and Brown, 2013; Geisler and Paro 2015; Grossniklaus and Paro 2014; Steffen and Ringrose, 2014; Ringrose 2017; Schuettengruber et al. 2017). Many PcG/TrxG binding sites give rise to noncoding transcripts (reviewed in Hekimoglu and Ringrose 2009 and Ringrose 2017). For instance, forward and reverse noncoding transcription has been detected from the Drosophila melanogaster vestigial (vg) PRE/TRE, which switches the status of the element between silencing (induced by transcription from the forward strand) and activation (induced by transcription from the reverse strand). Moreover, the non-coding transcripts from the reverse strand are able to bind to the PRC2 in vivo, inhibiting its enzymatic activity (Herzog et al. 2014). Additionally, since the initial discovery of lncRNA Xist targeting PcG to the inactive $\mathrm{X}$ chromosome in mammals (Plath et al. 2003), several lncRNAs in flies and mammals have been described to participate, not only in PcG-dependent silencing, but also in gene activation via disruption of PcG silencing or physical interaction with TrxG components (Geisler and Paro 2015; Schuettengruber et al. 2017). Altogether, the analyses of non-coding-mediated regulation of $\mathrm{PcG}$ and TrxG suggest that non-coding transcripts may be required to destabilize stable active and silent chromatin states, and to recruit or evict components of the PcG and TrxG complexes depending on their transcription rate (Ringrose 2017).

\section{LncRNAs modulating gene expression}

\section{LncRNAs transcribed from active enhancers (eRNAs)}

Transcription has been observed from multiple active enhancers in mammals (Andersson et al. 2014; Arner et al.
2015; De Santa et al. 2010; Kim et al. 2010), Drosophila (Henriques et al. 2018; Meers et al. 2018) and Caenorhabditis elegans (Chen et al. 2013). Although these enhancer RNAs (eRNAs) are not transcribed from all enhancer regions, a correlation has been observed between enhancer activity and the transcription of eRNAs both in mammals and flies (Hah et al. 2013; Mikhaylichenko et al. 2018). A growing number of studies demonstrate that specific eRNAs are required to properly activate the expression of their target genes (Ivaldi et al. 2018; Lai et al. 2013; Lam et al. 2013; Li et al. 2013; Rahnamoun et al. 2018; Schaukowitch et al. 2014; Tsai et al. 2018). In mammals, eRNAs have been associated with regulation of transcription through different mechanisms including: interaction and enhancement of the activity of chromatin regulators, like the acetyltransferase CREB binding protein(CBP), PRC2, MLL1 or $\mathrm{CTCF}$; influencing enhancer-promoter looping or altering RNA polymerase II elongation by interaction with proteins that either induce or inhibit elongation (reviewed in De Lara et al. 2019). However, as with the other types of IncRNAs, further studies are required to distinguish the eRNAs that actually play an active role in enhancer activity from those that might just be transcriptional noise arising from the presence of the RNA polymerase machinery. Although few eRNAs have been functionally characterised in flies, identification of general properties of eRNAs in Drosophila shows that eRNAs in flies share many characteristics with mammalian eRNAs, for instance, directionality, low abundance, correlation between expression and enhancer activity, or the presence of promoter-like motifs like INR motif (Mikhaylichenko et al. 2018).

\section{LncRNAs acting at post-transcriptional level}

\section{LncRNAs as a source of miRNAs}

MicroRNAs (miRNAs) are small non-coding transcripts (about 22 nucleotides) that play a major role in the posttranscriptional regulation of gene expression. In most cases, miRNAs are derived from the introns or exons of larger protein-coding or non-coding genes. In Drosophila, one of these non-coding transcripts, $i a b-8$, is transcribed primarily from the posterior central nervous system, beginning in early development (Bender 2008). It spans over $90 \mathrm{~kb}$ and is both spliced and polyadenylated (Bender 2008; Garaulet et al. 2014). Once transcribed, $i a b-8$ is processed into three miRNAs that altogether are called $m i R-i a b-8$, which are encoded within its intronic sequence. These miRNAs are known to target and downregulate the homeotic genes $a b d-A$ and $U b x$, as well as their cofactors $h t h$ and exd (Garaulet et al. 2014; Gummalla et al. 2012). The consequence of the loss of $i a b$ 8 is male and female sterility caused by the increase in the level of the transcripts targeted by miR-iab- 8 that is thought 
to elicit a defective innervation of the abdominal and/or reproductive tract muscles of the fly (Maeda et al. 2018). In mammals, several lncRNAs have been described as precursors of miRNAs, although none have been found to target the Hox genes. For instance, the maternally imprinted $H 19$ gene encodes one of the first lncRNAs described, which is a known precursor of miR-675 (Cai and Cullen 2007). H19 is highly transcribed in fetal tissues, where it is found to be processed into $m i R-675$, which limits placental growth by targeting, among others, growth promoting Igflr (Keniry et al. 2012). In parallel, H19 is also expressed in the adult skeletal muscle of humans and mice, where, instead of being processed into $m i R-675, H 19$ acts as a molecular sponge for the let-7 family of miRNAs (Kallen et al. 2013; Onyango and Feinberg 2011).

Another lncRNA that is processed into smaller RNAs is acal, which was described by Riesgo-Escovar and colleagues in 2015 (Ríos-Barrera et al. 2015). acal is one of the few Drosophila lncRNAs showing sequence conservation. In particular, a 296 nt-long fragment is $80 \%$ sequence identical in Drosophila melanogaster and Drosophila bipectinata. Also, a similar-sized lncRNA is found in humans, showing a considerable $48 \%$ sequence identity to Drosophila acal (Murillo-Maldonado and Riesgo-Escovar 2019). Mutations in acal are embryonic lethal and result in defects in dorsal closure, a JNK-dependent process that is essential for Drosophila embryogenesis. It was found that acal, through the regulation of two JNK modulators, Connector of kinase to APl ( $\mathrm{Cka}$ ) and anterior open (aop), is able to modulate JNK activity (Ríos-Barrera et al. 2015). Remarkably, acal is transcribed from a mono-exonic gene into a $2.3-\mathrm{kb}$ long transcript that, throughout the life cycle of the fly, particularly during pupal stages, is processed into smaller transcripts spanning from 50 to 120 nucleotides. The function of these small RNAs is yet to be investigated, but the differences in size with respect to the $\sim 22$ nucleotide miRNAs indicate that processed acal does not act as a typical miRNA (RíosBarrera et al. 2015).

\section{LncRNAs regulating isoform usage}

We recently identified blistered antisense (bsAS) as a natural antisense transcript of the blistered ( $b s$ ) gene involved in the regulation of $b s$ isoform usage in flies (Pérez-Lluch et al. 2020). The $b s$ gene encodes the Drosophila serum response factor (DSRF) and is a well characterised gene required for wing development and formation (Fristrom et al. 1994; Montagne et al. 1996; Roch et al. 1998). We have found that the usage of $b s$ isoforms is regulated in a tissue-specific manner by the expression of the $b s A S$. Transcription of $b s A S$ occurs specifically in wing intervein regions and impairs the expression of the long isoforms of $b s$, thereby promoting the relative expression of the short isoform. Overexpression of the long isoform in $b s A S$ mutants induces the formation of extra vein tissue in adult wings. The regulation of $b s$ isoform usage is based on the formation of a genomic loop between $b s$ and $b s A S$ promoters that impairs transcription of the long isoform and potentiates short isoform presence. This regulatory mechanism is totally independent of the presence of the $b s A s$ transcript, as $b s A S$ overexpression does not affect bs transcription.

A growing number of IncRNAs has been linked to the modulation of alternative splicing in mammals (reviewed in Romero-Barrios et al. 2018). For example, a natural antisense transcript regulates Zeb2/Sip1 expression during epithelial-mesenchymal transition in mammalian cells by preventing splicing of the Zeb2 5'-UTR (Beltran et al. 2008). An evolutionarily conserved nuclear antisense lncRNA, generated from the human fibroblast growth factor receptor 2 (FGFR2) locus, promotes epithelial-specific alternative splicing of FGFR2 (Gonzalez et al. 2015). This lncRNA impairs the binding of a repressive chromatin-splicing adaptor complex important for mesenchymal-specific splicing, by recruiting PcG proteins and the histone demethylase KDM2a. More recently, Singer and colleagues (Singer et al. 2019) characterised Paupar, a lncRNA that interacts with SR proteins to promote the alternative splicing of PAX6 in pancreatic glucagon-producing $\alpha$ cells and computational analysis of hepatocellular carcinoma RNA-Seq samples predicted hundreds of splicing-related lncRNAs (Wang et al. 2020).

\section{Other mechanisms of action of IncRNAs}

\section{LncRNAs encoding small functional peptides}

By definition, lncRNAs lack protein coding potential. Nevertheless, roughly $98 \%$ of the annotated lncRNAs in humans, mice and flies contain small open reading frames (smORFs) of 10 to 100 codons that may code for peptides (Couso and Patraquim 2017). The putative function of these peptides is, however, often neglected and the genes that encode them remain listed as non-coding. Translation of smORFs is observed in many eukaryotes (Andrews and Rothnagel 2014; Couso and Patraquim 2017), but examples of small functional peptides have been described primarily in humans (Anderson et al. 2015; D'Lima et al. 2017; Huang et al. 2017; Nelson et al. 2016; Slavoff et al. 2014; van Heesch et al. 2019) and insects (Galindo et al. 2007; Kondo et al. 2007; Magny et al. 2013). In Drosophila, the tarsal-less (tal) gene, previously classified as non-coding, encodes for a polycistronic mRNA that is translated into 4 small peptides of 11 amino acids. One of these peptides actively participates in leg development at the larval stage by regulating gene expression and tissue folding (Galindo et al. 2007) and at the pupal stage by modulating Notch signalling (Pueyo and Couso 2011). Moreover, the presence of 
similar smORFs in tal homologues across different species of insects suggests the presence of a conserved family of functional peptides (Galindo et al. 2007).

Ribosome profiling techniques (Ribo-seq), which specifically identify ribosome-bound transcripts, have corroborated that a fraction of lncRNAs have a strong affinity for ribosomes (Aspden et al. 2014; Bazzini et al. 2014; CarlevaroFita et al. 2016; Ingolia et al. 2011; Ruiz-Orera et al. 2014; van Heesch et al. 2014). However, the association with ribosomes does not necessarily imply that these lncRNAs are actively translated, since lncRNAs are known to regulate the translation of mRNAs through ribosome binding (Carrieri et al. 2012; Hansji et al. 2016; Liu et al. 2019; Yoon et al. 2012). To overcome this limitation, further studies on ribosome-bound lncRNAs should be taken: (1) to confirm whether they are translated and (2) to test the functionality of the translated smORFs. While peptide tagging or in vitro translation assays can be used to identify the coding potential of smORFs (Galindo et al. 2007; Pueyo and Couso 2011; van Heesch et al. 2019), the generation of knock-out mutants or the inhibition of the lncRNA transcription or translation should be considered to study their functionality (Anderson et al. 2015; Pueyo and Couso 2011).

The increasing number of functional smORFs encoded by genes annotated as lncRNAs challenges the current definition of lncRNAs. The fact that almost the totality of annotated lncRNAs present at least one predicted smORF within its sequence makes it impossible to rule them out just because of the smORF presence. However, to our understanding, the lncRNA status of those genes encoding for functionally validated smORFs should be revised or, on the contrary, the definition of IncRNA should be revised to include the genes encoding for functional smORFs.

\section{Expression of IncRNAs in development}

The first evidence of the involvement of mammalian lncRNAs in development came from high-throughput expression analyses of different tissues (Grote et al. 2013). Celltype and tissue specificities have been described for many lncRNAs and differential expression of lncRNAs has been reported in in vitro models of haematopoiesis, suggesting that they could have a role in the regulation of cell fate decisions (Briggs et al. 2015; Constanty and Shkumatava 2021; Perry and Ulitsky 2016; Schwarzer et al. 2017). Although most lncRNAs are still uncharacterised, a wide variety of functional activities have been associated with lncRNAs involved in development, such as the regulation of chromatin and DNA interactions, modulation of transcription factors, roles in mRNA stability and processing, and involvement in protein stability and function. Thus, an increasing number of human and mouse lncRNAs are being implicated as key regulators in a variety of cellular processes including proliferation, apoptosis and responses to stress. In agreement with observations in mammals, analyses based on the modENCODE RNA-Seq data from whole Drosophila animals have shown that a substantial number of lncRNAs are differentially expressed during development (referred to as developmentally dynamic lncRNAs), although some of the lncRNAs characterised were very lowly expressed (Chen et al. 2016; Brown et al. 2014; Lee et al. 2019; Li et al. 2019). Figure 2a shows the expression changes of the updated list of annotated lncRNAs in Drosophila (FlyBase r6.39, 2,545 lncRNAs) across fly development, using the modENCODE RNA-Seq data. Although different profiles of expression can be observed, a huge proportion of lncRNAs is upregulated towards the end of development, as previously reported (Graveley et al. 2011). Indeed, large changes of expression are detected for many genes specifically at the entrance of metamorphosis.

The expression patterns of developmentally dynamic lncRNAs in Drosophila are more restricted than those of protein-coding genes. Brown and colleagues reported that, on average, lncRNAs are expressed in a smaller number of stages and tissues compared to protein-coding genes (Brown et al. 2014). Remarkably, similarly restricted expression patterns have been reported for lncRNAs in humans and other mammals (Briggs et al. 2015; Constanty and Shkumatava 2021; Perry and Ulitsky 2016). Most studies characterising lncRNAs expression during development, either in Drosophila or in mammals, have been carried out using whole animals, which could be an important constraint considering the high level of tissue specificity that lncRNAs display. Interestingly, a recent publication from Kaessmann's group systematically described developmentally dynamic lncRNAs across several organs during mammalian development (Sarropoulos et al. 2019). After analysing the RNA-Seq data from seven species, the authors identified developmentally dynamic genes that displayed changes in expression during the development of mammalian organs, showing that the fraction of lncRNAs among this group of genes was substantially low considering the total proportion of lncRNAs in the human and mouse genomes (Sarropoulos et al. 2019). We took advantage of a previously published RNA-Seq data set from our group (Pérez-Lluch et al. 2020) containing the expression values for three tissues (eye, leg and wing) in three developmental stages (third instar larvae, early pupae and late pupae) to identify developmentally dynamic Drosophila genes, including lncRNA genes. We observed that the proportion of developmentally dynamic genes corresponding to IncRNAs is much lower in Drosophila (4\%) than humans and mice $(\sim 25 \%)$, which correlates with the lower number of annotated lncRNAs in flies (Fig. 2b).

We observed that the proportion of lncRNAs within developmentally dynamic genes in flies was lower $(3.3 \%)$ 
A

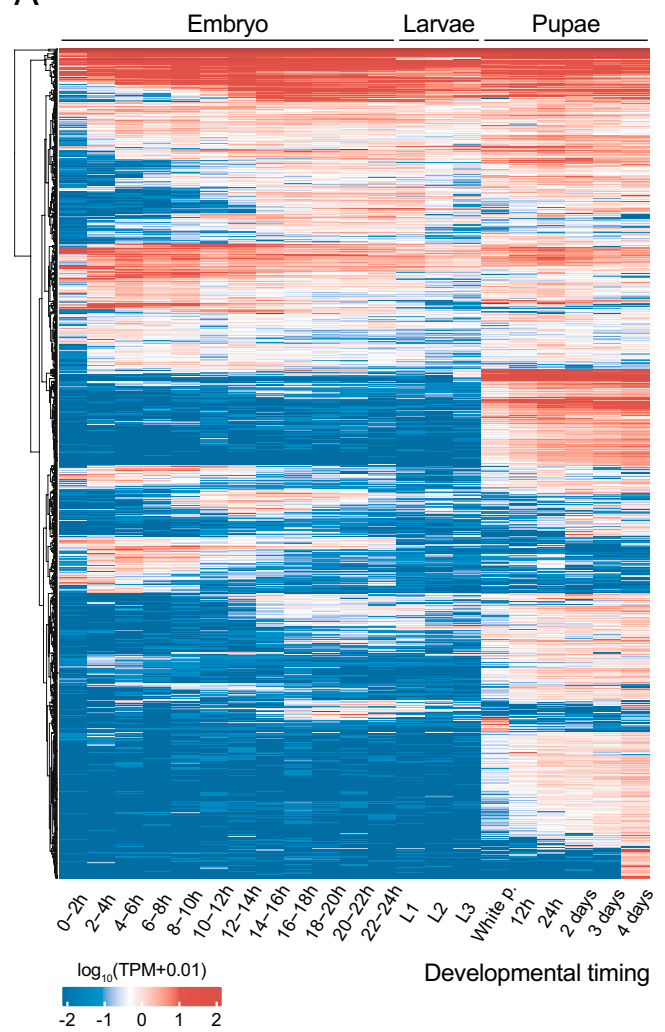

B

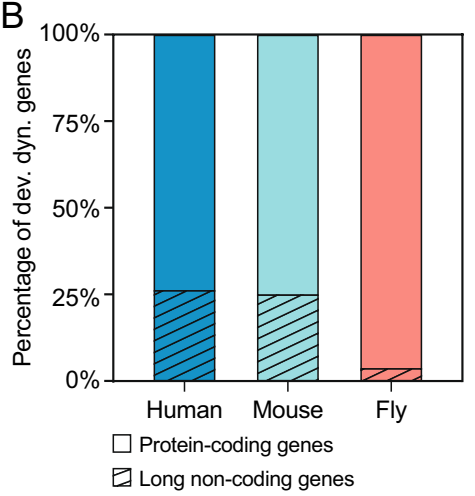

D

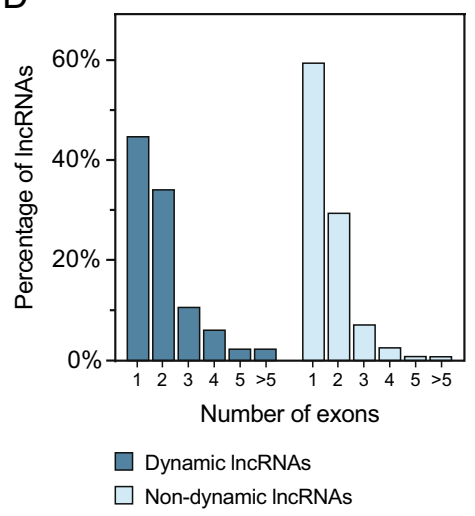

C

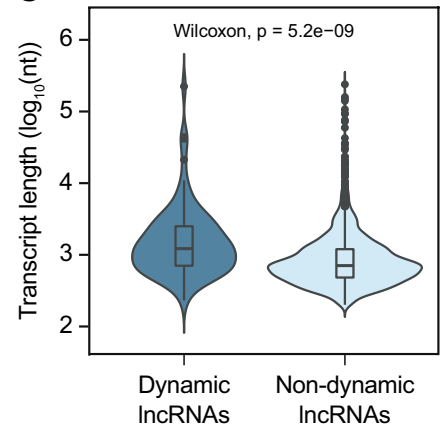

$\mathrm{E}$

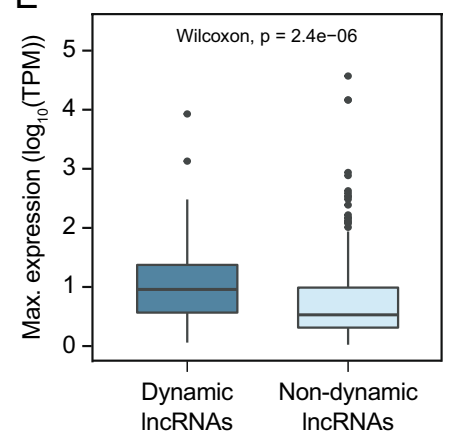

Fig. 2 Properties of Drosophila lncRNAs in development. a Heatmap showing the expression of all the annotated lncRNAs in Drosophila RNA-Seq samples from different developmental stages. b Percentage of developmentally dynamic genes corresponding to proteincoding and lncRNA genes in humans, mice and flies. Identification of developmentally dynamic genes was performed using edgeR on developmental RNA-Seq samples from Pérez-Lluch et al. (2020). c
Violin plot showing the distribution of Drosophila dynamic and nondynamic lncRNAs according to the length of their longest transcript. d Distribution of Drosophila dynamic and non-dynamic lncRNAs according to the number of exons in their longest transcript. e Boxplot showing the maximum expression across tissue development (expressed in $\log _{10}$ TPMs) of dynamic and non-dynamic lncRNAs in Drosophila

development are conserved in Drosophila developmentally dynamic lncRNAs. Although it is difficult to identify conservation of lncRNAs in different species, the fact that their properties are conserved suggests that some of their roles in development could be conserved, as well.

\section{Conservation}

LncRNA sequences are generally not conserved across different species, which severely hinders the identification of conserved IncRNAs that are likely to be functional. While protein-coding genes are constrained by a strong selective pressure to maintain their reading frame and codon synonymy, lncRNAs do not seem to depend on their sequence to perform their function, leading to their rapid evolution and sequence degeneration. Nevertheless, a few examples of lncRNAs whose sequence is conserved between different species of Drosophila have been described. This is the case of the previously discussed IncRNA acal or the 
yellow-achaete intergenic RNA (yar), which is a lncRNA involved in Drosophila sleep regulation. Several motifs ranging from 40 to $111 \mathrm{bp}$ located in the TSS, the exons and the 3 '-end of yar genomic sequence are conserved in different Drosophila species separated by as much as $40-60$ million years of evolution (Soshnev et al. 2011). However, it is not possible to find sequence similarity for most lncRNAs, thus, other types of conservation analysis are often used to discover orthologous IncRNAs in different organisms.

Synteny, the positional conservation of neighbouring genes across different species, has emerged as a valuable in identifying orthologous non-coding genes (Bryzghalov et al. 2021; Herrera-Úbeda et al. 2019; Pegueroles et al. 2019; Rolland et al. 2019). This analysis relies on the presence of orthologous genes located in the same order in the linear genome of different species. Syntenic conservation of the region surrounding the lncRNA locus could be an indicator of IncRNA orthology. However, the presence of a lncRNA conserved by synteny in different species does not necessarily imply orthology. Particularly, the presence of large intergenic regions containing multiple lncRNAs increases the rate of false positives (Young et al. 2012). In addition, since the analysis of synteny depends on the presence of orthologous genes, it works better in evolutionarily closer species and becomes less useful as the evolutionary distance increases between the species being compared. Around 60\% of protein-coding genes in Drosophila melanogaster have human homologues (Wangler et al. 2015), which is often not enough to find orthologous lncRNA genes consistently by the analysis of synteny. Nevertheless, the number of syntenic lincRNAs found in flies and mice is significantly higher than expected by chance, suggesting that a subset of those could be actual orthologs (Young et al. 2012), paving the way for further studies of IncRNAs in Drosophila.

Despite lacking sequence conservation, smaller regions of homology among different species have been observed for IncRNAs (Hezroni et al. 2015; Quinn et al. 2016; Ulitsky et al. 2011). These microhomologous regions are thought to correspond to functional elements that are essential for the function of the IncRNA, such as RNA-binding protein motifs or miRNA-binding sites. Recent studies have used a novel approach to identify orthologous lncRNAs based on the identification of these regions of microhomology. It is important to note that RNA-binding protein motifs or miRNA-binding sites are very short (between 4 and 12 nucleotides) and individual matches between different species can be found purely by chance (Bartel 2018). An interesting approach to bypass the rate of false positive hits is the addition of order to these elements (Ross et al. 2021). In this way, not only the presence of these motifs is considered, but also the order in which they are found in putatively orthologous lncRNAs. Although this method has not been tested for distantly related species, finding small regions of homology should be more achievable than finding orthologous lncRNAs using the current methods based on whole-sequence similarity or secondary structure predictions.

Another type of conservation analysis is the study of IncRNA secondary structures, which are thought to be more conserved than the primary sequence (Graf and Kretz 2020; Smith et al. 2013). Unfortunately, the currently available secondary structure predicting tools are not very accurate. Most of these programmes use a minimum free energy algorithm, which predicts the optimal secondary structure that requires the minimum energy to fold. However, features such as the presence of RNA-binding motifs, which should be located outside of the main structure to be properly recognised by their binding proteins, are not taken into consideration. Although it could be a reliable alternative for confirming the orthologous genes identified by other methods, the current secondary structure prediction tools do not seem accurate enough to consider the RNA folding form as the primary source to identify orthologous lncRNAs.

Another approach to identify potential IncRNAs orthologous is through the analysis of their pattern of binding to protein coding genes. If lncRNAs from different species bind to the same orthologous protein coding genes, they may exert a similar function. Methods have been developed to estimate the binding propensity of protein-RNA pairs in silico (Agostini et al. 2013; Armaos et al. 2021; Bellucci et al. 2011). However, to date, this approach has not been tested on a large scale to identify ortholog lncRNAs. To date, no reliable methods exist to systematically establish conservation among lncRNAs in evolutionarily distant species like flies and humans. However, the huge amount of effort made in that direction and the increasing number of annotated transcripts that will emerge in the coming years, hint to a promising perspective regarding lncRNA orthology. The fact that many functions and features associated with lncRNAs are conserved in Drosophila reinforces its extraordinary potential as a model organism to functionally characterise and model lncRNAs.

Finally, the characterisation of genomes across the tree of life will provide an incredible amount of data to perform comparative analyses. Advances in sequencing technologies that enable the identification of complete genomes have led to the emergence of the Earth BioGenome Project, an international collaboration that aims to sequence, catalogue and characterise the genomes of all eukaryotes on Earth (Lewin et al. 2018). One of the outcomes of this project is the production of new knowledge on the organisation and evolution of genomes, which could also have a major impact on the field of lncRNAs.

Author contributions CC-R, MC and MR-R conceived the idea of this article and performed the literature search. Data analysis was 
performed by CC-R, RA, CCK and MR-R. The first draft of the manuscript was written by CC-R, MC and MR-R and all authors commented on previous versions of the manuscript. All authors read and approved the final manuscript.

Funding This project was funded by Grants: BFU2015-67623-P and PGC2018-099763-B100, 2017SGR1455 from AGAUR (Generalitat de Catalunya) and a Grant from the Institució Catalana de Recerca i Estudis Avançats (via an ICREA Academia award) to M.C.; as well as support from the European Community under the FP7 programme (ERC-2011-AdG-294653-RNA-MAPS), 2U41 HG007234-05G from NIH/NHGRI (USA) and the Grant PGC2018-094017-B-I00 from the Spanish Ministerio de Ciencia, Innovación y Universidades to R.G.. C.C.-R. holds a predoctoral FPI contract from the Spanish Government (Ministerio de Ciencia e Innovación). R.A. is a predoctoral fellow of CONACYT, the "Becas al Extranjero" Program of Mexico.

Data availability Not applicable.

Code availability Not applicable.

\section{Declarations}

Conflict of interest The authors declare no conflict of interest.

Ethical approval Not applicable.

Consent to participate All authors consent to participate in this manuscript.

Consent for publication All authors consent for the publication of this manuscript.

Open Access This article is licensed under a Creative Commons Attribution 4.0 International License, which permits use, sharing, adaptation, distribution and reproduction in any medium or format, as long as you give appropriate credit to the original author(s) and the source, provide a link to the Creative Commons licence, and indicate if changes were made. The images or other third party material in this article are included in the article's Creative Commons licence, unless indicated otherwise in a credit line to the material. If material is not included in the article's Creative Commons licence and your intended use is not permitted by statutory regulation or exceeds the permitted use, you will need to obtain permission directly from the copyright holder. To view a copy of this licence, visit http://creativecommons.org/licenses/by/4.0/.

\section{References}

Adams MD, Celniker SE, Holt RA, Evans CA, Gocayne JD, Amanatides PG, Scherer SE, Li PW et al (2000) The genome sequence of Drosophila melanogaster. Science 287:2185-2195

Agostini F, Zanzoni A, Klus P, Marchese D, Cirillo D, Tartaglia GG (2013) catRAPID omics: a web server for large-scale prediction of protein-RNA interactions. Bioinformatics 29:2928-2930. https://doi.org/10.1093/bioinformatics/btt495

Anderson DM, Anderson KM, Chang CL, Makarewich CA, Nelson BR, McAnally JR, Kasaragod P, Shelton JM et al (2015) A micropeptide encoded by a putative long noncoding RNA regulates muscle performance. Cell 160:595-606. https://doi.org/10. 1016/j.cell.2015.01.009
Andersson R, Gebhard C, Miguel-Escalada I, Hoof I, Bornholdt J, Boyd M, Chen Y, Zhao X et al (2014) An atlas of active enhancers across human cell types and tissues. Nature 507:455-461. https://doi.org/10.1038/nature12787

Andrews SJ, Rothnagel JA (2014) Emerging evidence for functional peptides encoded by short open reading frames. Nat Rev Genet 15:193-204. https://doi.org/10.1038/nrg3520

Armaos A, Colantoni A, Proietti G, Rupert J, Tartaglia GG (2021) cat RAPID omics v2.0: going deeper and wider in the prediction of protein-RNA interactions. Nucleic Acids Res. https://doi.org/ 10.1093/nar/gkab393

Arner E, Daub CO, Vitting-Seerup K, Andersson R, Lilje B, Drabløs F, Lennartsson A, Rönnerblad M et al (2015) Transcribed enhancers lead waves of coordinated transcription in transitioning mammalian cells. Science 347:1010-1014. https://doi.org/ 10.1126/science. 1259418

Aspden JL, Eyre-Walker YC, Phillips RJ, Amin U, Mumtaz MAS, Brocard M, Couso J-P (2014) Extensive translation of small Open reading frames revealed by poly-Ribo-Seq. Elife 3:1-19. https:// doi.org/10.7554/eLife.03528

Bartel DP (2018) Metazoan microRNAs. Cell 173:20-51. https://doi. org/10.1016/j.cell.2018.03.006

Bazzini AA, Johnstone TG, Christiano R, MacKowiak SD, Obermayer B, Fleming ES, Vejnar CE, Lee MT et al (2014) Identification of small ORFs in vertebrates using ribosome footprinting and evolutionary conservation. EMBO J 33:981-993. https://doi.org/ 10.1002/embj.201488411

Beckmann K, Grskovic M, Gebauer F, Hentze MW (2005) A dual inhibitory mechanism restricts msl-2 mRNA translation for dosage compensation in Drosophila. Cell 122:529-540. https://doi. org/10.1016/j.cell.2005.06.011

Bellucci M, Agostini F, Masin M, Tartaglia GG (2011) Predicting protein associations with long noncoding RNAs. Nat Methods 8:444-445. https://doi.org/10.1038/nmeth.1611

Beltran M, Puig I, Pena C, Garcia JM, Alvarez AB, Pena R, Bonilla F, de Herreros AG (2008) A natural antisense transcript regulates Zeb2/Sip1 gene expression during Snail1-induced epithelialmesenchymal transition. Genes Dev 22:756-769. https://doi. org/10.1101/gad.455708

Bender W (2008) MicroRNAs in the Drosophila bithorax complex. Genes Dev 22:14-19. https://doi.org/10.1101/gad.1614208

Bier E (2005) Drosophila, the golden bug, emerges as a tool for human genetics. Nat Rev Genet 6:9-23. https://doi.org/10.1038/nrg1503

Bone JR, Lavender J, Richman R, Palmer MJ, Turner BM, Kuroda MI (1994) Acetylated histone H4 on the male X chromosome is associated with dosage compensation in Drosophila. Genes Dev 8:96-104. https://doi.org/10.1101/gad.8.1.96

Briggs JA, Wolvetang EJ, Mattick JS, Rinn JL, Barry G (2015) Mechanisms of long non-coding RNAs in mammalian nervous system development, plasticity, disease, and evolution. Neuron 88:861877. https://doi.org/10.1016/j.neuron.2015.09.045

Brockdorff N, Ashworth A, Kay GF, McCabe VM, Norris DP, Cooper PJ, Swift S, Rastan S (1992) The product of the mouse Xist gene is a $15 \mathrm{~kb}$ inactive $\mathrm{X}$-specific transcript containing no conserved ORF and located in the nucleus. Cell 71:515-526. https://doi.org/ 10.1016/0092-8674(92)90519-I

Brown CJ, Ballabio A, Rupert JL, Lafreniere RG, Grompe M, Tonlorenzi R, Willard HF (1991) A gene from the region of the human $\mathrm{X}$ inactivation centre is expressed exclusively from the inactive X chromosome. Nature 349:38-44. https://doi.org/10. 1038/349038a0

Brown CJ, Hendrich BD, Rupert JL, Lafrenière RG, Xing Y, Lawrence J, Willard HF (1992) The human XIST gene: analysis of a $17 \mathrm{~kb}$ inactive X-specific RNA that contains conserved repeats and is 
highly localized within the nucleus. Cell 71:527-542. https://doi. org/10.1016/0092-8674(92)90520-M

Brown JB, Boley N, Eisman R, May GE, Stoiber MH, Duff MO, Booth BW, Wen J et al (2014) Diversity and dynamics of the Drosophila transcriptome. Nature 512:393-399. https://doi.org/10. 1038/nature 12962

Bryzghalov O, Makałowska I, Szcześniak MW (2021) lncEvo: automated identification and conservation study of long noncoding RNAs. BMC Bioinform. https://doi.org/10.1186/ s12859-021-03991-2

Cai X, Cullen BR (2007) The imprinted H19 noncoding RNA is a primary microRNA precursor. RNA 13:313-316. https://doi.org/ 10.1261/rna.351707

Cao L, Zhang P, Li J, Wu M (2017) Last, a c-Myc-inducible long noncoding RNA, cooperates with CNBP to promote CCND1 MRNA stability in human cells. Elife. https://doi.org/10.7554/ eLife. 30433

Carlevaro-Fita J, Rahim A, Guigó R, Vardy LA, Johnson R (2016) Cytoplasmic long noncoding RNAs are frequently bound to and degraded at ribosomes in human cells. RNA 22:867-882. https:// doi.org/10.1261/rna.053561.115

Carrieri C, Cimatti L, Biagioli M, Beugnet A, Zucchelli S, Fedele S, Pesce E, Ferrer I et al (2012) Long non-coding antisense RNA controls Uchl1 translation through an embedded SINEB2 repeat. Nature 491:454-457. https://doi.org/10.1038/nature11508

Chan CS, Rastelli L, Pirrotta V (1994) A Polycomb response element in the Ubx gene that determines an epigenetically inherited state of repression. EMBO J 13:2553-2564. https://doi.org/10.1002/j. 1460-2075.1994.tb06545.x

Chen RAJ, Down TA, Stempor P, Chen QB, Egelhofer TA, Hillier LDW, Jeffers TE, Ahringer J (2013) The landscape of RNA polymerase II transcription initiation in C. elegans reveals promoter and enhancer architectures. Genome Res 23:1339-1347. https:// doi.org/10.1101/gr.153668.112

Chen B, Zhang Y, Zhang X, Jia S, Chen S, Kang L (2016) Genomewide identification and developmental expression profiling of long noncoding RNAs during Drosophila metamorphosis. Sci Rep 6:1-8. https://doi.org/10.1038/srep23330

Consortium MGS, Brent MR, Birren BW, Antonarakis SE, Alexandersson M, Zody M, Birney E, Baertsch R et al (2002) Initial sequencing and comparative analysis of the mouse genome. Nature 420:520-562. https://doi.org/10.1038/nature01262

Constanty F, Shkumatava A (2021) LncRNAs in development and differentiation: from sequence motifs to functional characterization. Development. https://doi.org/10.1242/dev.182741

Couso J-P, Patraquim P (2017) Classification and function of small open reading frames. Nat Rev Mol Cell Biol 18:575-589. https:// doi.org/10.1038/nrm.2017.58

D'Lima NG, Ma J, Winkler L, Chu Q, Loh KH, Corpuz EO, Budnik BA, Lykke-Andersen J et al (2017) A human microprotein that interacts with the mRNA decapping complex. Nat Chem Biol 13:174-180. https://doi.org/10.1038/nchembio.2249

De Lara JCF, Arzate-Mejía RG, Recillas-Targa F (2019) Enhancer RNAs: insights into their biological role. Epigenet Insights. https://doi.org/10.1177/2516865719846093

De Santa F, Barozzi I, Mietton F, Ghisletti S, Polletti S, Tusi BK, Muller H, Ragoussis J et al (2010) A large fraction of extragenic RNA Pol II transcription sites overlap enhancers. PLoS Biol. https://doi.org/10.1371/journal.pbio.1000384

Derrien T, Johnson R, Bussotti G, Tanzer A, Djebali S, Tilgner H, Guernec G, Martin D et al (2012) The GENCODE v7 catalog of human long noncoding RNAs: analysis of their gene structure, evolution, and expression. Genome Res 22:1775-1789. https:// doi.org/10.1101/gr.132159.111

Dong Y, Liang G, Yuan B, Yang C, Gao R, Zhou X (2015) MALAT1 promotes the proliferation and metastasis of osteosarcoma cells by activating the PI3K/Akt pathway. Tumor Biol 36:1477-1486. https://doi.org/10.1007/s13277-014-2631-4

Fristrom D, Gotwals P, Eaton S, Kornberg TB, Sturtevant M, Bier E, Fristrom JW (1994) blistered: a gene required for vein/intervein formation in wings of Drosophila. Development 120:2661-2671

Galindo MI, Pueyo JI, Fouix S, Bishop SA, Couso JP (2007) Peptides encoded by short ORFs control development and define a new eukaryotic gene family. PLoS Biol 5:1052-1062. https://doi.org/ 10.1371/journal.pbio.0050106

Gao F, Cai Y, Kapranov P, Xu D (2020) Reverse-genetics studies of lncRNAs - what we have learnt and paths forward. Genome Biol 21:93. https://doi.org/10.1186/s13059-020-01994-5

Garaulet DL, Castellanos MC, Bejarano F, Sanfilippo P, Tyler DM, Allan DW, Sánchez-Herrero E, Lai EC (2014) Homeotic function of Drosophila bithorax-complex miRNAs mediates fertility by restricting multiple Hox genes and TALE cofactors in the CNS. Dev Cell 29:635-648. https://doi.org/10.1016/j. devcel.2014.04.023

Gebauer F, Merendino L, Hentze MW, Valcárcel J (1998) The Drosophila splicing regulator sex-lethal directly inhibits translation of male-specific-lethal 2 mRNA. RNA 4:142-150

Geisler SJ, Paro R (2015) Trithorax and Polycomb group-dependent regulation: a tale of opposing activities. Development 142:2876-2887. https://doi.org/10.1242/dev.120030

Gelbart ME, Larschan E, Peng S, Park PJ, Kuroda MI (2009) Drosophila MSL complex globally acetylates H4K16 on the male $\mathrm{X}$ chromosome for dosage compensation. Nat Struct Mol Biol 16:825-832. https://doi.org/10.1038/nsmb.1644

Gonzalez I, Munita R, Agirre E, Dittmer TA, Gysling K, Misteli T, Luco RF (2015) A lncRNA regulates alternative splicing via establishment of a splicing-specific chromatin signature. Nat Struct Mol Biol 22:370-376. https://doi.org/10.1038/nsmb. 3005

Graf J, Kretz M (2020) From structure to function: Route to understanding lncRNA mechanism. BioEssays. https://doi.org/10. 1002/bies.202000027

Graindorge A, Carré C, Gebauer F (2013) Sex-lethal promotes nuclear retention of msl2 mRNA via interactions with the STAR protein HOW. Genes Dev 27:1421-1433. https://doi.org/10.1101/gad. 214999.113

Graveley BR, Brooks AN, Carlson JW, Duff MO, Landolin JM, Yang L, Artieri CG, Van Baren MJ et al (2011) The developmental transcriptome of Drosophila melanogaster. Nature 471:473-479. https://doi.org/10.1038/nature09715

Grossniklaus U, Paro R (2014) Transcriptional silencing by polycombgroup proteins. Cold Spring Harb Perspect Biol 6:1-26. https:// doi.org/10.1101/cshperspect.a019331

Grote P, Herrmann BG (2013) The long non-coding RNA Fendrr links epigenetic control mechanisms to gene regulatory networks in mammalian embryogenesis. RNA Biol 10:1579-1585. https:// doi.org/10.4161/rna.26165

Grote P, Wittler L, Hendrix D, Koch F, Währisch S, Beisaw A, Macura K, Bläss G et al (2013) The tissue-specific lncRNA Fendrr is an essential regulator of heart and body wall development in the mouse. Dev Cell 24:206-214. https://doi.org/10.1016/j.devcel. 2012.12.012

Gumireddy K, Li A, Yan J, Setoyama T, Johannes GJ, Ørom UA, Tchou J, Liu Q et al (2013) Identification of a long non-coding RNAassociated RNP complex regulating metastasis at the translational step. EMBO J 32:2672-2684. https://doi.org/10.1038/ emboj.2013.188

Gummalla M, Maeda RK, Alvarez JJ, Gyurkovics H, Singari S, Edwards KA, Karch F, Bender W (2012) Abd-A regulation by the iab-8 noncoding RNA. PLoS Genet. https://doi.org/10.1371/ journal.pgen. 1002720 
Hah N, Murakami S, Nagari A, Danko CG, Lee Kraus W (2013) Enhancer transcripts mark active estrogen receptor binding sites. Genome Res 23:1210-1223. https://doi.org/10.1101/gr.152306. 112

Hansji H, Leung EY, Baguley BC, Finlay GJ, Cameron-Smith D, Figueiredo VC, Askarian-Amiri ME (2016) ZFAS1: a long noncoding RNA associated with ribosomes in breast cancer cells. Biol Direct 11:62. https://doi.org/10.1186/s13062-016-0165-y

He R-Z, Luo D-X, Mo Y-Y (2019) Emerging roles of lncRNAs in the post-transcriptional regulation in cancer. Genes Dis 6:6-15. https://doi.org/10.1016/j.gendis.2019.01.003

Hekimoglu B, Ringrose L (2009) Non-coding RNAs in polycomb/ trithorax regulation. RNA Biol 6:129-137. https://doi.org/10. 4161/rna.6.2.8178

Henriques T, Scruggs BS, Inouye MO, Muse GW, Williams LH, Burkholder AB, Lavender CA, Fargo DC et al (2018) Widespread transcriptional pausing and elongation control at enhancers. Genes Dev 32:26-41. https://doi.org/10.1101/gad.309351.117

Herrera-Úbeda C, Barba MM, Pérez EN, Gravemeyer J, AlbuixechCrespo B, Wheeler GN, Garcia-Fernàndez J (2019) Microsyntenic clusters reveal conservation of lncRNAs in chordates despite absence of sequence conservation. Biology (basel). https://doi.org/10.3390/biology8030061

Herzog VA, Lempradl A, Trupke J, Okulski H, Altmutter C, Ruge F, Boidol B, Kubicek S et al (2014) A strand-specific switch in noncoding transcription switches the function of a polycomb/ trithorax response element. Nat Genet 46:973-981. https://doi. org/10.1038/ng.3058

Hezroni H, Koppstein D, Schwartz MG, Avrutin A, Bartel DP, Ulitsky I (2015) Principles of long noncoding RNA evolution derived from direct comparison of transcriptomes in 17 species. Cell Rep 11:1110-1122. https://doi.org/10.1016/j.celrep.2015.04.023

Huang J-Z, Chen M, Chen D, Gao X-C, Zhu S, Huang H, Hu M, Zhu $\mathrm{H}$ et al (2017) A peptide encoded by a putative lncRNA HOXBAS3 suppresses colon cancer growth. Mol Cell 68:171-184.e6. https://doi.org/10.1016/j.molcel.2017.09.015

Ingolia NT, Lareau LF, Weissman JS (2011) Ribosome profiling of mouse embryonic stem cells reveals the complexity and dynamics of mammalian proteomes. Cell 147:789-802. https://doi.org/ 10.1016/j.cell.2011.10.002

Ivaldi MS, Diaz LF, Chakalova L, Lee J, Krivega I, Dean A (2018) Fetal $\gamma$-globin genes are regulated by the BGLT3 long noncoding RNA locus. Blood 132:1963-1973. https://doi.org/10.1182/ blood-2018-07-862003

Jandura A, Krause HM (2017) The new RNA world: growing evidence for long noncoding RNA functionality. Trends Genet 33:665676. https://doi.org/10.1016/j.tig.2017.08.002

Ji J-Y, Han C, Deng W-M (2019) Understanding human diseases using Drosophila. J Genet Genomics 46:155-156. https://doi.org/10. 1016/j.jgg.2019.04.001

Jiang W, Liu Y, Liu R, Zhang K, Zhang Y (2015) The lncRNA DEANR1 facilitates human endoderm differentiation by activating FOXA2 expression. Cell Rep 11:137-148. https://doi.org/10. 1016/j.celrep.2015.03.008

Johnson R (2012) Long non-coding RNAs in Huntington's disease neurodegeneration. Neurobiol Dis 46:245-254. https://doi.org/ 10.1016/j.nbd.2011.12.006

Kallen AN, Zhou XB, Xu J, Qiao C, Ma J, Yan L, Lu L, Liu C et al (2013) The imprinted H19 lncRNA antagonizes Let-7 microRNAs. Mol Cell 52:101-112. https://doi.org/10.1016/j.molcel. 2013.08.027

Kassis JA, Brown JL (2013) Polycomb group response elements in Drosophila and vertebrates. In: Kumar D (ed) Advances in genetics, 1st edn. Elsevier Inc., Cardiff, pp 83-118
Kassis JA, Kennison JA, Tamkun JW (2017) Polycomb and trithorax group genes in drosophila. Genetics 206:1699-1725. https://doi. org/10.1534/genetics.115.185116

Keniry A, Oxley D, Monnier P, Kyba M, Dandolo L, Smits G, Reik W (2012) The H19 lincRNA is a developmental reservoir of miR675 that suppresses growth and Igf1r. Nat Cell Biol 14:659-665. https://doi.org/10.1038/ncb2521

Kim TK, Hemberg M, Gray JM, Costa AM, Bear DM, Wu J, Harmin DA, Laptewicz M et al (2010) Widespread transcription at neuronal activity-regulated enhancers. Nature 465:182-187. https:// doi.org/10.1038/nature09033

Kondo T, Hashimoto Y, Kato K, Inagaki S, Hayashi S, Kageyama Y (2007) Small peptide regulators of actin-based cell morphogenesis encoded by a polycistronic mRNA. Nat Cell Biol 9:660-665. https://doi.org/10.1038/ncb1595

Lagarde J, Uszczynska-Ratajczak B, Carbonell S, Pérez-Lluch S, Abad A, Davis C, Gingeras TR, Frankish A et al (2017) High-throughput annotation of full-length long noncoding RNAs with capture long-read sequencing. Nat Genet 49:1731-1740. https://doi.org/ 10.1038/ng.3988

Lai F, Orom UA, Cesaroni M, Beringer M, Taatjes DJ, Blobel GA, Shiekhattar R (2013) Activating RNAs associate with mediator to enhance chromatin architecture and transcription. Nature 494:497-501. https://doi.org/10.1038/nature11884

Lam MTY, Cho H, Lesch HP, Gosselin D, Heinz S, Tanaka-Oishi Y, Benner C, Kaikkonen MU et al (2013) Rev-Erbs repress macrophage gene expression by inhibiting enhancer-directed transcription. Nature 498:511-515. https://doi.org/10.1038/natur e12209

Lander ES, Linton LM, Birren B, Nusbaum C, Zody MC, Baldwin J, Devon K, Dewar K et al (2001) Correction: initial sequencing and analysis of the human genome. Nature 412:565-566. https:// doi.org/10.1038/35087627

Lee JT, Strauss WM, Dausman JA, Jaenisch R (1996) A 450 kb transgene displays properties of the mammalian $\mathrm{X}$-inactivation center. Cell 86:83-94. https://doi.org/10.1016/S0092-8674(00) 80079-3

Lee DY, Moon J, Lee S-T, Jung K-H, Park D-K, Yoo J-S, Sunwoo J-S, Byun J-I et al (2015) Distinct expression of long non-coding RNAs in an Alzheimer's disease model. J Alzheimer's Dis 45:837-849. https://doi.org/10.3233/JAD-142919

Lee S, Kopp F, Chang TC, Sataluri A, Chen B, Sivakumar S, Yu H, Xie $Y$ et al (2016) Noncoding RNA NORAD regulates genomic stability by sequestering Pumilio proteins. Cell 164:69-80. https:// doi.org/10.1016/j.cell.2015.12.017

Lee H, Zhang Z, Krause HM (2019) Long noncoding RNAs and repetitive elements: junk or intimate evolutionary partners? Trends Genet 35:892-902. https://doi.org/10.1016/j.tig.2019.09.006

Legeai F, Derrien T (2015) Identification of long non-coding RNAs in insects genomes. Curr Opin Insect Sci 7:37-44. https://doi.org/ 10.1016/j.cois.2015.01.003

Lewin HA, Robinson GE, Kress WJ, Baker WJ, Coddington J, Crandall KA, Durbin R, Edwards SV et al (2018) Earth BioGenome project: sequencing life for the future of life. Proc Natl Acad Sci USA 115:4325-4333

Li M, Wen S, Guo X, Bai B, Gong Z, Liu X, Wang Y, Zhou Y et al (2012) The novel long non-coding RNA CRG regulates Drosophila locomotor behavior. Nucleic Acids Res 40:11714-11727. https://doi.org/10.1093/nar/gks943

Li W, Notani D, Ma Q, Tanasa B, Nunez E, Chen AY, Merkurjev D, Zhang J et al (2013) Functional roles of enhancer RNAs for oestrogen-dependent transcriptional activation. Nature 498:516520. https://doi.org/10.1038/nature12210

Li H, Yu B, Li J, Su L, Yan M, Zhu Z, Liu B (2014) Overexpression of lncRNA H19 enhances carcinogenesis and metastasis of gastric 
cancer. Oncotarget 5:2318-2329. https://doi.org/10.18632/oncot arget.1913

Li F, Cao L, Hang D, Wang F, Wang Q (2015) Long non-coding RNA HOTTIP is up-regulated and associated with poor prognosis in patients with osteosarcoma. Int J Clin Exp Pathol 8:11414-11420

Li K, Tian Y, Yuan Y, Fan X, Yang M, He Z, Yang D (2019) Insights into the functions of IncRNAs in Drosophila. Int J Mol Sci 20:4646. https://doi.org/10.3390/ijms20184646

Liu SJ, Horlbeck MA, Cho SW, Birk HS, Malatesta M, He D, Attenello FJ, Villalta JE et al (2017) CRISPRi-based genome-scale identification of functional long noncoding RNA loci in human cells. Science 355:7111. https://doi.org/10.1126/science.aah7111

Liu Y, Cao Z, Wang Y, Guo Y, Xu P, Yuan P, Liu Z, He Y et al (2018) Genome-wide screening for functional long noncoding RNAs in human cells by Cas 9 targeting of splice sites. Nat Biotechnol 36:1203-1210. https://doi.org/10.1038/nbt.4283

Liu PY, Tee AE, Milazzo G, Hannan KM, Maag J, Mondal S, Atmadibrata B, Bartonicek N et al (2019) The long noncoding RNA lncNB1 promotes tumorigenesis by interacting with ribosomal protein RPL35. Nat Commun 10:5026. https://doi. org/10.1038/s41467-019-12971-3

Lo Piccolo L, Yamaguchi M (2017) RNAi of arcRNA hsrw affects sub-cellular localization of Drosophila FUS to drive neurodiseases. Exp Neurol 292:125-134. https://doi.org/10.1016/j. expneurol.2017.03.011

Maeda RK, Sitnik JL, Frei Y, Prince E, Gligorov D, Wolfner MF, Karch F (2018) The lncRNA male-specific abdominal plays a critical role in Drosophila accessory gland development and male fertility. PLoS Genet. https://doi.org/10.1371/journal. pgen.1007519

Magny EG, Pueyo JI, Pearl FMG, Cespedes MA, Niven JE, Bishop SA, Couso JP (2013) Conserved regulation of cardiac calcium uptake by peptides encoded in small open reading frames. Science 341:1116-1120. https://doi.org/10.1126/science.1238802

Mallo M, Alonso CR (2013) The regulation of Hox gene expression during animal development. Development 140:3951-3963. https://doi.org/10.1242/dev.068346

Meers MP, Adelman K, Duronio RJ, Strahl BD, McKay DJ, Matera AG (2018) Transcription start site profiling uncovers divergent transcription and enhancer-associated RNAs in Drosophila melanogaster. BMC Genomics. https://doi.org/10.1186/ s12864-018-4510-7

Meller VH, Rattner BP (2002) The roX genes encode redundant malespecific lethal transcripts required for targeting of the MSL complex. EMBO J 21:1084-1091. https://doi.org/10.1093/emboj/ 21.5.1084

Mikhaylichenko O, Bondarenko V, Harnett D, Schor IE, Males M, Viales RR, Furlong EEM (2018) The degree of enhancer or promoter activity is reflected by the levels and directionality of eRNA transcription. Genes Dev 32:42-57. https://doi.org/10. 1101/gad.308619.117

Montagne J, Groppe J, Guillemin K, Krasnow MA, Gehring WJ, Affolter M (1996) The Drosophila serum response factor gene is required for the formation of intervein tissue of the wing and is allelic to blistered. Development 122:2589-2597

Murillo-Maldonado JM, Riesgo-Escovar JR (2019) The various and shared roles of lncRNAs during development. Dev Dyn 248:1059-1069. https://doi.org/10.1002/dvdy.108

Nelson BR, Makarewich CA, Anderson DM, Winders BR, Troupes CD, Wu F, Reese AL, McAnally JR et al (2016) A peptide encoded by a transcript annotated as long noncoding RNA enhances SERCA activity in muscle. Science 351:271-275. https://doi.org/10.1126/ science.aad4076

Onyango P, Feinberg AP (2011) A nucleolar protein, H19 opposite tumor suppressor (HOTS), is a tumor growth inhibitor encoded by a human imprinted H19 antisense transcript. Proc Natl Acad
Sci USA 108:16759-16764. https://doi.org/10.1073/pnas.11109 04108

Paytuví Gallart A, Hermoso Pulido A, Martínez A, de Lagrán I, Sanseverino W, Aiese Cigliano R (2016) GREENC: a Wiki-based database of plant lncRNAs. Nucleic Acids Res 44:D1161D1166. https://doi.org/10.1093/nar/gkv1215

Pegueroles C, Iraola-Guzmán S, Chorostecki U, Ksiezopolska E, Saus E, Gabaldón T (2019) Transcriptomic analyses reveal groups of co-expressed, syntenic lncRNAs in four species of the genus Caenorhabditis. RNA Biol 16:320-329. https://doi.org/10.1080/ 15476286.2019.1572438

Penny GD, Kay GF, Sheardown SA, Rastan S, Brockdorff N (1996) Requirement for Xist in X chromosome inactivation. Nature 379:131-137. https://doi.org/10.1038/379131a0

Pérez-Lluch S, Klein CC, Breschi A, Ruiz-Romero M, Abad A, Palumbo E, Bekish L, Arnan C et al (2020) bsAS, an antisense long non-coding RNA, essential for correct wing development through regulation of blistered/DSRF isoform usage. PLoS Genet. https://doi.org/10.1371/journal.pgen.1009245

Perry RB-T, Ulitsky I (2016) The functions of long noncoding RNAs in development and stem cells. Development 143:3882-3894. https://doi.org/10.1242/dev.140962

Pervouchine DD, Djebali S, Breschi A, Davis CA, Barja PP, Dobin A, Tanzer A, Lagarde J et al (2015) Enhanced transcriptome maps from multiple mouse tissues reveal evolutionary constraint in gene expression. Nat Commun 6:5903. https://doi.org/10.1038/ ncomms6903

Plath K, Fang J, Mlynarczyk-Evans SK, Cao R, Worringer KA, Wang $\mathrm{H}$, de la Cruz CC, Otte AP et al (2003) Role of histone H3 lysine 27 methylation in X inactivation. Science 300:131-135. https:// doi.org/10.1126/science.1084274

Prensner JR, Iyer MK, Sahu A, Asangani IA, Cao Q, Patel L, Vergara IA, Davicioni E et al (2013) The long noncoding RNA SChLAP1 promotes aggressive prostate cancer and antagonizes the SWI/ SNF complex. Nat Genet 45:1392-1398. https://doi.org/10.1038/ ng. 2771

Pueyo JI, Couso JP (2011) Tarsal-less peptides control Notch signalling through the Shavenbaby transcription factor. Dev Biol 355:183193. https://doi.org/10.1016/j.ydbio.2011.03.033

Quinn JJ, Zhang QC, Georgiev P, Ilik IA, Akhtar A, Chang HY (2016) Rapid evolutionary turnover underlies conserved lncRNAgenome interactions. Genes Dev 30:191-207. https://doi.org/ $10.1101 / \operatorname{gad} .272187 .115$

Rahnamoun H, Lee J, Sun Z, Lu H, Ramsey KM, Komives EA, Lauberth SM (2018) RNAs interact with BRD4 to promote enhanced chromatin engagement and transcription activation. Nat Struct Mol Biol 25:687-697. https://doi.org/10.1038/ s41594-018-0102-0

Ramilowski JA, Yip CW, Agrawal S, Chang J-C, Ciani Y, Kulakovskiy IV, Mendez M, Ooi JLC et al (2020) Corrigendum: functional annotation of human long noncoding RNAs via molecular phenotyping. Genome Res 30:1377. https://doi.org/10.1101/gr.270330. 120

Ringrose L (2017) Noncoding RNAs in polycomb and trithorax regulation: a quantitative perspective. Annu Rev Genet. https://doi.org/ 10.1146/annurev-genet-120116

Rinn JL, Kertesz M, Wang JK, Squazzo SL, Xu X, Brugmann SA, Goodnough LH, Helms JA et al (2007) Functional demarcation of active and silent chromatin domains in human HOX loci by noncoding RNAs. Cell 129:1311-1323. https://doi.org/10.1016/j. cell.2007.05.022

Ríos-Barrera LD, Gutiérrez-Pérez I, Domínguez M, Riesgo-Escovar JR (2015) acal is a long non-coding RNA in JNK signaling in epithelial shape changes during Drosophila dorsal closure. PLoS Genet 11:1-27. https://doi.org/10.1371/journal.pgen.1004927 
Roch F, Baonza A, Martín-Blanco E, García-Bellido A (1998) Genetic interactions and cell behaviour in blistered mutants during proliferation and differentiation of the Drosophila wing. Development 125:1823-1832

Rogoyski OM, Pueyo JI, Couso JP, Newbury SF (2017) Functions of long non-coding RNAs in human disease and their conservation in Drosophila development. Biochem Soc Trans 45:895-904. https://doi.org/10.1042/BST20160428

Rolland AD, Evrard B, Darde TA, Le Beguec C, Le Bras Y, Bensalah K, Lavoue S, Jost B et al (2019) RNA profiling of human testicular cells identifies syntenic lncRNAs associated with spermatogenesis. Hum Reprod 34:1278-1290. https://doi.org/10.1093/ humrep/dez063

Romero-Barrios N, Legascue MF, Benhamed M, Ariel F, Crespi M (2018) Splicing regulation by long noncoding RNAs. Nucleic Acids Res 46:2169-2184. https://doi.org/10.1093/nar/gky095

Ross CJ, Rom A, Spinrad A, Gelbard-Solodkin D, Degani N, Ulitsky I (2021) Uncovering deeply conserved motif combinations in rapidly evolving noncoding sequences. Genome Biol. https://doi. org/10.1186/s13059-020-02247-1

Ruiz-Orera J, Messeguer X, Subirana JA, Alba MM (2014) Long noncoding RNAs as a source of new peptides. Elife 3:1-24. https:// doi.org/10.7554/eLife.03523

Samata M, Akhtar A (2018) Dosage compensation of the X chromosome: a complex epigenetic assignment involving chromatin regulators and long noncoding RNAs. Annu Rev Biochem 87:323350. https://doi.org/10.1146/annurev-biochem-062917-011816

Sarropoulos I, Marin R, Cardoso-Moreira M, Kaessmann H (2019) Developmental dynamics of lncRNAs across mammalian organs and species. Nature 571:510-514. https://doi.org/10.1038/ s41586-019-1341-x

Schaukowitch K, Joo JY, Liu X, Watts JK, Martinez C, Kim TK (2014) Enhancer RNA facilitates NELF release from immediate early genes. Mol Cell 56:29-42. https://doi.org/10.1016/j.molcel.2014. 08.023

Schor IE, Bussotti G, Maleš M, Forneris M, Viales RR, Enright AJ, Furlong EEM (2018) Non-coding RNA expression, function, and variation during Drosophila embryogenesis. Curr Biol 28:35473561. https://doi.org/10.1016/j.cub.2018.09.026

Schuettengruber B, Bourbon H-M, Di Croce L, Cavalli G (2017) Genome regulation by polycomb and trithorax: 70 years and counting. Cell 171:34-57. https://doi.org/10.1016/j.cell.2017. 08.002

Schwarzer A, Emmrich S, Schmidt F, Beck D, Ng M, Reimer C, Adams FF, Grasedieck S et al (2017) The non-coding RNA landscape of human hematopoiesis and leukemia. Nat Commun 8:1-17. https://doi.org/10.1038/s41467-017-00212-4

Simon J, Chiang A, Bender W, Shimell MJ, O’Connor M (1993) Elements of the Drosophila bithorax complex that mediate repression by polycomb group products. Dev Biol 158:131-144. https://doi.org/10.1006/dbio.1993.1174

Singer RA, Arnes L, Cui Y, Wang J, Gao Y, Guney MA, Burnum-Johnson KE, Rabadan R et al (2019) The long noncoding RNA paupar modulates PAX6 regulatory activities to promote alpha cell development and function. Cell Metab 30:1091-1106. https:// doi.org/10.1016/j.cmet.2019.09.013

Slavoff SA, Heo J, Budnik BA, Hanakahi LA, Saghatelian A (2014) A human short open reading frame (sORF)-encoded polypeptide that stimulates DNA end joining. J Biol Chem 289:10950-10957. https://doi.org/10.1074/jbc.C113.533968

Smith MA, Gesell T, Stadler PF, Mattick JS (2013) Widespread purifying selection on RNA structure in mammals. Nucleic Acids Res 41:8220-8236. https://doi.org/10.1093/nar/gkt596

Soshnev AA, Ishimoto H, Mcallister BF, Li X, Wehling MD, Kitamoto T, Geyer PK (2011) A conserved long noncoding RNA affects sleep behavior in Drosophila. Genetics 189(2):455-468. https:// doi.org/10.1534/GENETICS.111.131706

St Johnston D (2002) The art and design of genetic screens: Drosophila melanogaster. Nat Rev Genet 3:176-188. https://doi.org/10.1038/ $\operatorname{nrg} 751$

Statello L, Guo C-J, Chen L-L, Huarte M (2021) Gene regulation by long non-coding RNAs and its biological functions. Nat Rev Mol Cell Biol 22:96-118. https://doi.org/10.1038/ s41580-020-00315-9

Steffen PA, Ringrose L (2014) What are memories made of? How polycomb and trithorax proteins mediate epigenetic memory. Nat Rev Mol Cell Biol 15:340-356. https://doi.org/10.1038/nrm3789

Tripathi V, Ellis JD, Shen Z, Song DY, Pan Q, Watt AT, Freier SM, Bennett CF et al (2010) The nuclear-retained noncoding RNA MALAT1 regulates alternative splicing by modulating SR splicing factor phosphorylation. Mol Cell 39:925-938. https://doi.org/ 10.1016/j.molcel.2010.08.011

Tsai PF, Dell'Orso S, Rodriguez J, Vivanco KO, Ko KD, Jiang K, Juan AH, Sarshad AA et al (2018) A muscle-specific enhancer RNA mediates cohesin recruitment and regulates transcription in trans. Mol Cell 71:129-141. https://doi.org/10.1016/j.molcel. 2018.06.008

Ulitsky I, Shkumatava A, Jan CH, Sive H, Bartel DP (2011) Conserved function of lincRNAs in vertebrate embryonic development despite rapid sequence evolution. Cell 147:1537-1550. https:// doi.org/10.1016/j.cell.2011.11.055

van Heesch S, Van Iterson M, Jacobi J, Boymans S, Essers PB, De Bruijn E, Hao W, MacInnes AW et al (2014) Extensive localization of long noncoding RNAs to the cytosol and mono- and polyribosomal complexes. Genome Biol. https://doi.org/10.1186/ gb-2014-15-1-r6

van Heesch S, Witte F, Schneider-Lunitz V, Schulz JF, Adami E, Faber $\mathrm{AB}$, Kirchner M, Maatz $\mathrm{H}$ et al (2019) The translational landscape of the human heart. Cell 178:242-260.e29. https://doi.org/ 10.1016/j.cell.2019.05.010

Venter JC, Adams MD, Myers EW, Li PW, Mural RJ, Sutton GG, Smith HO, Yandell M et al (2001) The sequence of the human genome. Science 291:1304-1351. https://doi.org/10.1126/scien ce. 1058040

Wang J, Wang X, Bhat A, Chen Y, Xu K, Mo YY, Yi SS, Zhou Y (2020) Comprehensive network analysis reveals alternative splicing-related lncRNAs in hepatocellular carcinoma. Front Genet. https://doi.org/10.3389/fgene.2020.00659

Wangler MF, Yamamoto S, Bellen HJ (2015) Fruit flies in biomedical research. Genetics 199:639-653. https://doi.org/10.1534/genet ics.114.171785

Wen K, Yang L, Xiong T, Di C, Ma D, Wu M, Xue Z, Zhang X et al (2016) Critical roles of long noncoding RNAs in Drosophila spermatogenesis. Genome Res 26:1233-1244. https://doi.org/ 10.1101/gr.199547.115

Wu Z-H, Wang X-L, Tang H-M, Jiang T, Chen J, Lu S, Qiu G-Q, Peng $\mathrm{Z}-\mathrm{H}$ et al (2014) Long non-coding RNA HOTAIR is a powerful predictor of metastasis and poor prognosis and is associated with epithelial-mesenchymal transition in colon cancer. Oncol Rep 32:395-402. https://doi.org/10.3892/or.2014.3186

Wutz A, Jaenisch R (2000) A shift from reversible to irreversible X inactivation is triggered during ES cell differentiation. Mol Cell 5:695-705. https://doi.org/10.1016/S1097-2765(00)80248-8

Wutz A, Rasmussen TP, Jaenisch R (2002) Chromosomal silencing and localization are mediated by different domains of Xist RNA. Nat Genet 30:167-174. https://doi.org/10.1038/ng820

Yap KL, Li S, Muñoz-Cabello AM, Raguz S, Zeng L, Mujtaba S, Gil J, Walsh MJ et al (2010) Molecular interplay of the noncoding RNA ANRIL and methylated histone $\mathrm{H} 3$ lysine 27 by polycomb CBX7 in transcriptional silencing of INK4a. Mol Cell 38:662674. https://doi.org/10.1016/j.molcel.2010.03.021 
Yoon JH, Abdelmohsen K, Srikantan S, Yang X, Martindale JL, De S, Huarte M, Zhan M et al (2012) LincRNA-p21 suppresses target mRNA translation. Mol Cell 47:648-655. https://doi.org/10. 1016/j.molcel.2012.06.027

Young RS, Marques AC, Tibbit C, Haerty W, Bassett AR, Liu J-L, Ponting CP (2012) Identification and properties of 1,119 candidate LincRNA loci in the drosophila melanogaster genome. Genome Biol Evol 4:427-442. https://doi.org/10.1093/gbe/evs020

Zhou Y, Zhong Y, Wang Y, Zhang X, Batista DL, Gejman R, Ansell PJ, Zhao J et al (2007) Activation of p53 by MEG3 non-coding RNA. J Biol Chem 282:24731-24742. https://doi.org/10.1074/ jbc.M702029200
Zu T, Liu Y, Banez-Coronel M, Reid T, Pletnikova O, Lewis J, Miller TM, Harms MB et al (2013) RAN proteins and RNA foci from antisense transcripts in C9ORF72 ALS and frontotemporal dementia. Proc Natl Acad Sci 110:E4968-E4977. https://doi. org/10.1073/pnas.1315438110

Publisher's Note Springer Nature remains neutral with regard to jurisdictional claims in published maps and institutional affiliations. 